\title{
Surface mass-balance observations and automatic weather station data along a transect near Kangerlussuaq, West Greenland
}

\author{
R.S.W. VAN DE WAL, W. GREUELL, M.R. VAN DEN BROEKE, \\ C.H. REIJMER, J. OERLEMANS \\ Institute for Marine and Atmospheric Research Utrecht, Utrecht University, 3508 TA Utrecht, The Netherlands \\ E-mail:wal@phys.uu.nl
}

\begin{abstract}
Surface mass-balance data from the Kangerlussuaq transect (K-transect) located on the western part of the Greenland ice sheet near $67^{\circ} \mathrm{N}$ are presented. The series covers the period 19902003 and is the longest series of surface mass-balance measurements in Greenland. The surface massbalance measurements cover an altitude range of 390-1850 m and show a linear increase of the specific mass balance, with a mass-balance gradient of $3.7 \times 10^{-3} \mathrm{~m} \mathrm{~m}^{-1}$ and a mean equilibrium-line altitude of $\mathbf{1 5 3 5} \mathrm{m}$ a.s.I. Interannual variability shows a weak 4 yearly periodicity. In addition to the surface massbalance data, automatic weather station data at an elevation of approximately $1010 \mathrm{~m}$ are available for the period 1997-2002. These data are used to explain observed surface mass-balance anomalies over the same 5 years. It is shown that variations in shortwave radiation dominate interannual variability. The mean annual cycle of temperature is characterized by a maximum in summer around the melting point, leading to a mean summer outgoing longwave radiation of approximately $314 \mathrm{~W} \mathrm{~m}^{-2}$. The mean annual cycle in wind speed shows a maximum in winter (on average around $8 \mathrm{~m} \mathrm{~s}^{-1}$ ) and a minimum in summer (on average around $5 \mathrm{~m} \mathrm{~s}^{-1}$ ), which is characteristic for a katabatic forcing. During summer the net radiation is on average about $61 \mathrm{~W} \mathrm{~m}^{-2}$, which is used for ice melting at a rate of typically $2 \mathrm{~cm} \mathrm{w.e.} \mathrm{d}^{-1}$. Net radiation contributes $84 \%$ of the total energy used for summer melting averaged over the 5 years.
\end{abstract}

\section{INTRODUCTION}

Mass-balance observations are a key to the validation of models aimed at calculating volume changes of an ice sheet. In recent years, our understanding of accumulation over Greenland has significantly improved (Thomas, 2004). A weak point in the observational evidence for massbalance changes relates to the ablation area (e.g. Van de Wal, 2004). This is due partly to the large logistical efforts required for fieldwork, but also to the limited possibility of remote-sensing techniques. As a result, time series of massbalance measurements in the ablation area spanning several decades do not exist for Greenland. Reeh (1991) and Van de Wal (1996) summarized 1-7years of surface mass-balance observations from six transects. A more general study of the internannual variability of the mass balance over the entire ice sheet is presented by Six and others (2001). This study indicates spatial homogeneous variations in the ablation area, but not in the accumulation zone. Here, we report on what is, to our knowledge, the longest currently available mass-balance series from the ablation zone.

Measurements have been performed since 1990 along a transect near Kangerlussuaq (K-transect) at $67^{\circ} \mathrm{N}$ on the western part of the Greenland ice sheet (Fig. 1). This area is characterized by relatively high ablation $\left(4-5 \mathrm{~m} \mathrm{a}^{-1}\right.$ near the margin) and low accumulation $\left(0.3 \mathrm{mw}^{\mathrm{e}} \mathrm{e} \cdot \mathrm{a}^{-1}\right)$. The measurements are a follow-up to two micrometeorological experiments carried out in the summers of 1990 and 1991. Results were described in a special issue of Global and Planetary Change (volume 9) in 1994. In addition, we initiated automatic weather station (AWS) measurements in the ablation area in the mid-1990s. Results of the surface mass-balance measurements were presented by Van de Wal and others (1996) and Greuell and others (2001). Here, we

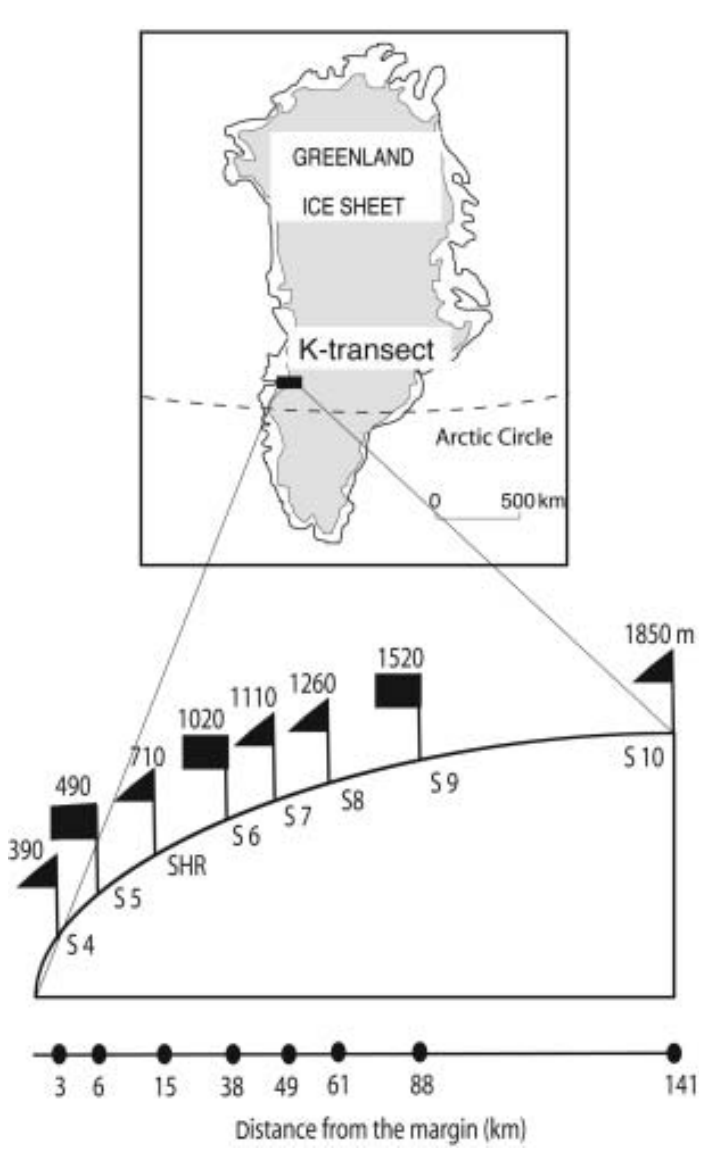

Fig. 1. The K-transect. The triangles indicate mass-balance sites, the squares AWS sites in August 2004. The elevations are the average elevation over the period 1996-2002 as measured by global positioning system. 
Table 1. Surface mass-balance measurements (in mw.e.) along the K-transect at $67^{\circ} \mathrm{N}$. Distances are presented in kilometres from the western ice margin

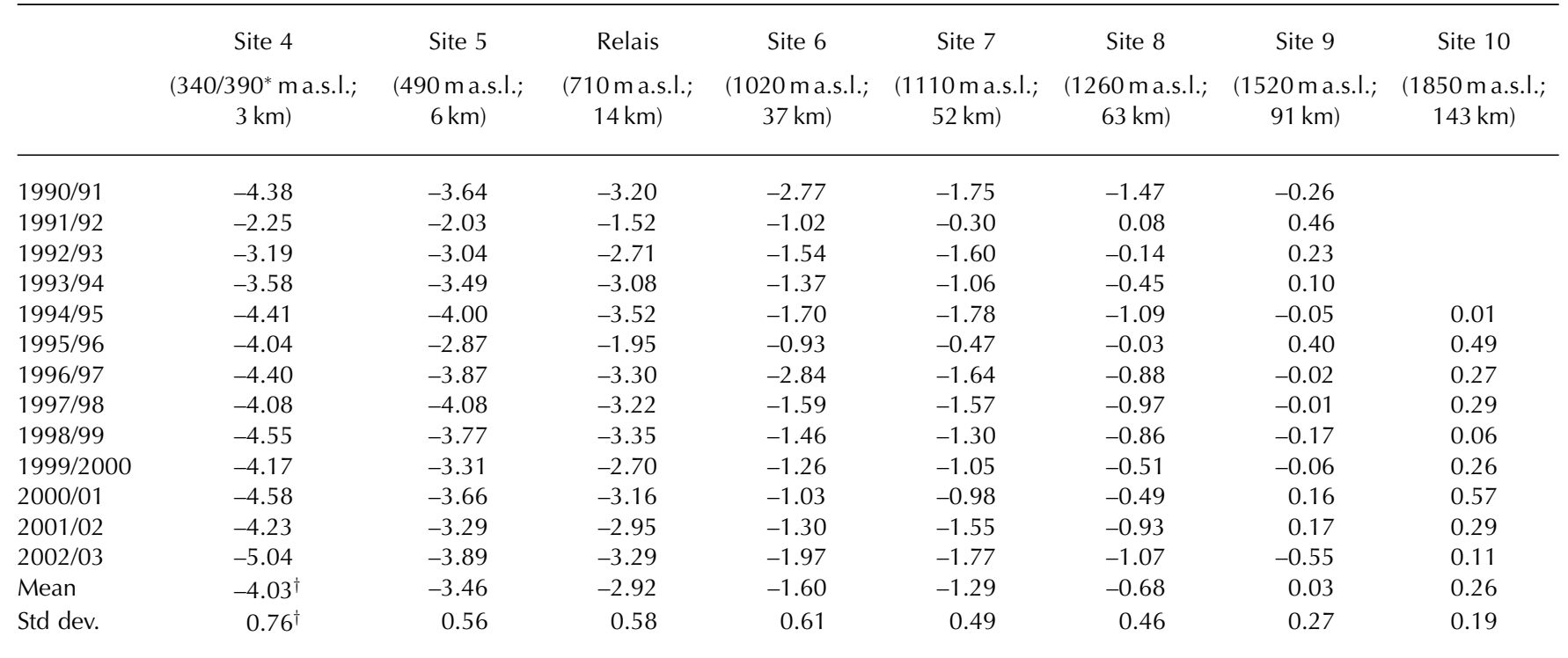

*First 3 years at $340 \mathrm{~m}$ a.s.l., thereafter at $390 \mathrm{~m}$ a.s.l.

†Data over first 3 years are recalculated from $340 \mathrm{~m}$ a.s.l. to $390 \mathrm{~m}$ a.s.l. with the mean surface mass-balance gradient of $3.7 \times 10^{-3} \mathrm{~m} \mathrm{~m}^{-1}$ in order to calculate mean and standard deviation.

extend the earlier record of surface mass-balance measurements to the period 1990-2003 (section 2) and show some first results from the AWS (1020 ma.s.l.) over the last 5 years of the surface mass-balance record (section 3 ). Sonic height ranger data provide insight into ablation and accumulation processes on an hourly basis over the entire year. These data are used for an energy closure approach in

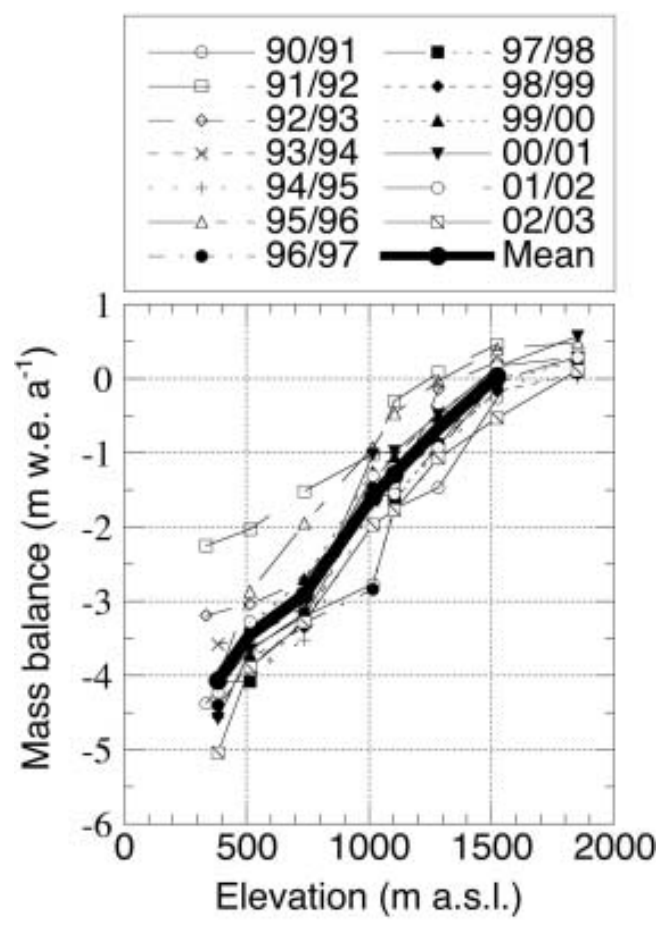

Fig. 2. Surface mass-balance measurements as a function of elevation, for the period 1990-2003. The thick line is the mean over the entire period. order to explain the interannual variability in the ablation during a summer month (section 4).

\section{SURFACE MASS-BALANCE MEASUREMENTS}

The transect runs from an elevation of approximately $390 \mathrm{~m}$ near the margin to an elevation of $1850 \mathrm{~m}$ in the accumulation zone. Altogether, eight sites are used to study the change of the surface mass balance with elevation. Six sites are located in the ablation area, one near the equilibrium line and one in the accumulation zone. Visits to the sites were made by helicopter, usually around 20 August, except in 1990 (21 July), 1991 (5 August) and 1992 (12 August). This means that the first three mass-balance years are slightly longer than a year and that no separate winter balance data are available.

At each site, at least two stakes were maintained throughout the entire period. The data presented in Table 1 and Figure 2 are the mean values of the individual stake readings. Length changes are converted to surface mass balance by assuming an ice density of $900 \mathrm{~kg} \mathrm{~m}^{-3}$, except at the highest site where the density of the snowpack was measured. Internal accumulation was not measured. Figure 2 shows the surface mass balance as a function of elevation for each individual year. The mean equilibrium-line altitude (ELA) is $1535 \mathrm{~m}$ a.s.l, near site 9, and the average surface mass-balance gradient is $3.7 \times 10^{-3} \mathrm{~m} \mathrm{~m}^{-1}$ in the ablation area. This gradient is comparable to that measured at other sites in West Greenland (e.g. Thomsen, 1987; Braithwaite and Olesen, 1989).

Though the average surface mass balance increases almost linearly with elevation, strong deviations occur in measurements for single years. The deviations are concentrated around an elevation of $1000 \mathrm{~m}$. The years 1990/91 and 1996/97, in particular, show a steepening of the surface mass-balance gradient. The years 1992/93, 1994/95 and 2001/02 show a reversed pattern, with higher ablation rates at $1100 \mathrm{~m}$ a.s.l. than at $1000 \mathrm{~m}$ a.s.l. These deviations are 
Table 2. AWS sensor specifications. EADT is estimated accuracy for daily totals

\begin{tabular}{llll}
\hline Sensor & Type & Range & Accuracy \\
\hline Air temperature & Aanderaa 3145 & $-44^{\circ} \mathrm{C}$ to $+49^{\circ} \mathrm{C}$ & $0.1^{\circ} \mathrm{C}$ \\
Wind speed & Aanderaa 2740 & $0-76 \mathrm{~m} \mathrm{~s}^{-1}$ & $2 \%$, or \\
& & & $0.2 \mathrm{~m} \mathrm{~s}^{-1}$ \\
Wind direction & Aanderaa 2750 & $0-360^{\circ}$ & $5^{\circ}$ \\
Air pressure & Vaisala PTA427 & $600-1060 \mathrm{hPa}$ & $0.5 \mathrm{hPa}$ \\
$\begin{array}{l}\text { Pyranometer } \\
\text { Pyrradiometer }\end{array}$ & Kipp en Zonen CM3 & $0.305-2.8 \mu \mathrm{m}$ & $10 \%$ of EADT \\
$\begin{array}{l}\text { Sonic height } \\
\text { ranger }\end{array}$ & Campbell SR50 & $5.0-50 \mu \mathrm{m}$ & $10 \%$ of EADT \\
& & $0.4-10 \mathrm{~m}$ & $0.01 \mathrm{~m}$, or \\
& & & $0.4 \%$ \\
\hline
\end{tabular}

likely caused by changes in the albedo (e.g. Greuell and Knap, 2000).

Figure 3 shows the interannual variation of surface mass balance averaged along the transect, calculated both as a weighted average and as an arithmetical average. For the weighted average, the distance between the sites was taken into account. The weighing factor is taken to be proportional to distance between the neighbouring points. Since the distance between the sites increases with elevation, the weight of the individual sites increases with elevation. This opposes to some extent the observation that the interannual variations are largest in the lower parts of the ablation area. For this reason, we also show in Figure 3 the arithmetical average of the sites. The figure shows that there is no trend in the data, but rather some periodicity. A spectral analysis shows a peak at 4 years with a significance level of $70 \%$. Here, it should be kept in mind that the entire series is only 13 years long and that the first three mass-balance years are slightly longer than a year, which might cause some bias in the averaged data presented in Figure 3.

\section{AUTOMATIC WEATHER STATION MEASUREMENTS}

In this study, we also use data from an AWS situated at site 6 . Five years of measurements are available covering the period 1997-2002. Measurements of radiation, temperature, wind speed and direction were performed at a height of approximately $4 \mathrm{~m}$ above the surface during the period 1997-2000 and at 6 and $2 \mathrm{~m}$ above the surface from 2001 onwards. Air pressure was measured in the electronics enclosure close to the surface (Table 2). The mast construction rests on four

Table 3. Basic meteorological quantities over the period 1997-2002 at site 6 along the K-transect. Data are mean annual data

$\begin{array}{llllll}1998 & 1999 & 2000 & 2001 & 2002 & 1998-2002\end{array}$

\begin{tabular}{lcccccc}
\hline Temperature $\left({ }^{\circ} \mathrm{C}\right)$ & -10.1 & $-10.8^{*}$ & -11.3 & -10.4 & -10.7 & -10.6 \\
Wind speed $\left(\mathrm{m} \mathrm{s}^{-1}\right)$ & 6.4 & $5.9^{*}$ & $6.3^{\#}$ & 6.1 & 5.8 & 6.1 \\
$S_{\text {in }}\left(\mathrm{W} \mathrm{m}^{-2}\right)$ & 124 & 135 & 134 & 131 & 128 & 130 \\
$S_{\text {reflected }}\left(\mathrm{W} \mathrm{m}^{-2}\right)$ & 88 & 96 & 96 & 100 & 94 & 95 \\
$L_{\text {in }}\left(\mathrm{W} \mathrm{m}^{-2}\right)$ & 236 & $230^{*}$ & 232 & 231 & - & $232^{+}$ \\
$L_{\text {out }}\left(\mathrm{W} \mathrm{m}^{-2}\right)$ & 270 & $266^{*}$ & 266 & 269 & - & $268^{+}$ \\
$R_{\text {net }}\left(\mathrm{W} \mathrm{m}^{-2}\right)$ & 0 & 3 & 3 & -7 & - & $0^{+}$ \\
\hline
\end{tabular}

*No data in November. ${ }^{\#}$ No data over the months March-July. ${ }^{+} 1998-2001$.

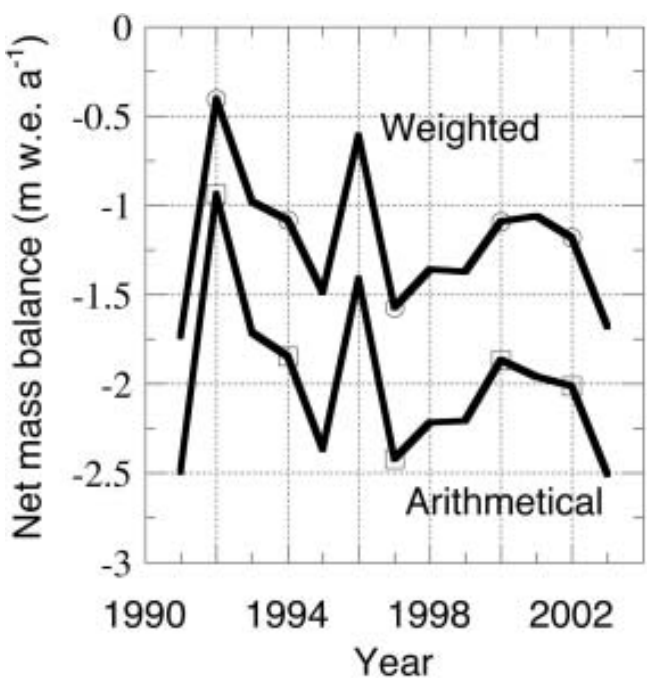

Fig. 3. Averaged surface mass balance for sites 4-9 over the entire period. The upper curve shows the weighted mean, and the lower curve the arithmetical mean (see text). Spectral analyses show a weak 4 year periodicity. Measurements were done at $340 \mathrm{~m}$ a.s.l. for the first 3 years, thereafter at 390 ma.s.l.

legs, and sinks with the surface during the ablation period. As a result, the measurement height is more or less constant in time. Data were sampled instantaneously every 6 min (but wind speed is cumulative), then averaged and stored every hour for the period 1997-2001 and every 0.5 hours in 2002 on a Campbell CR10 data logger.

\subsection{Meteorological characteristics at $\mathbf{1 0 2 0} \mathrm{m}$ a.s.I.}

The meteorological conditions are summarized in Tables 3 and 4 . In Table 3 we present the annual mean temperature, wind speed and radiation components, and in Table 4 their averages over the summer period. The summer period is defined as the months June-August, during which most of the ablation takes place. It is observed that variations in the different meteorological quantities are limited. If one defines interannual variability as the standard deviation among the different years divided by the mean of a quantity, one finds variations of only $4-5 \%$ for wind speed, shortwave incoming radiation, reflected shortwave radiation and incoming longwave radiation. The variation in mean outgoing longwave radiation is even smaller (only $1 \%$ ). The latter can be attributed to the dominant signature of the temperature, with a flat maximum around melting point during the three summer months at 1020 ma.s.l.

Table 4. As Table 3, but now for the summer period only (June-August)

$1998 \quad 1999 \quad 2000 \quad 2001 \quad 2002 \quad 1998-2002$

\begin{tabular}{lcccccc}
\hline Temperature $\left({ }^{\circ} \mathrm{C}\right)$ & 0.1 & -0.3 & 0.4 & 0.4 & 0.9 & 0.3 \\
Wind speed $\left(\mathrm{m} \mathrm{s}^{-1}\right)$ & 4.2 & 5.4 & - & 5.0 & 3.9 & 4.6 \\
$S_{\text {in }}\left(\mathrm{W} \mathrm{m}^{-2}\right)$ & 251 & 271 & 261 & 275 & 243 & 260 \\
$S_{\text {reflected }}\left(\mathrm{W} \mathrm{m}^{-2}\right)$ & 139 & 169 & 156 & 179 & 146 & 158 \\
$L_{\text {in }}\left(\mathrm{W} \mathrm{m}^{-2}\right)$ & 273 & 273 & 274 & 267 & - & $272^{+}$ \\
$L_{\text {out }}\left(\mathrm{W} \mathrm{m}^{-2}\right)$ & 314 & 312 & 315 & 315 & - & $314^{+}$ \\
$R_{\text {net }}\left(\mathrm{W} \mathrm{m}^{-2}\right)$ & 70 & 63 & 64 & 48 & - & $61^{+}$ \\
\hline
\end{tabular}

+1998-2001. 


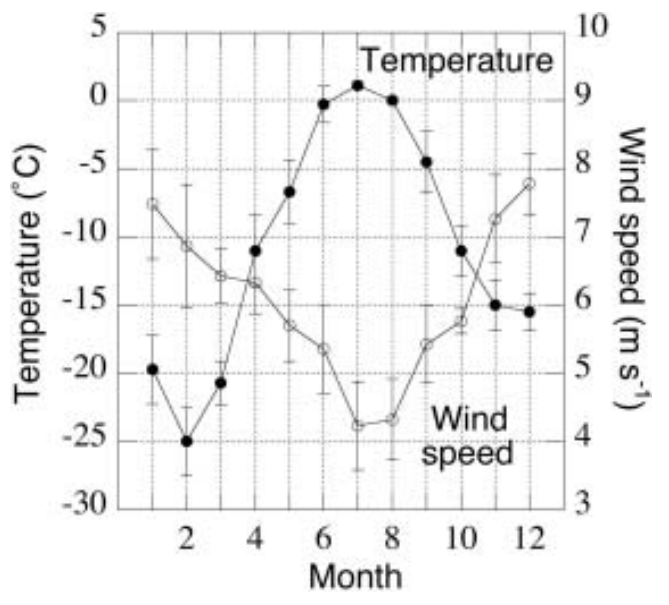

Fig. 4. Average seasonal cycle (1997-2002), based on monthly means, of temperature and wind speed at site 6 .

Figure 4 presents the mean yearly cycle for the station temperature and wind speed. Katabatic forcing is strongest in winter, leading to $6 \mathrm{~m}$ wind speeds of approximately $8 \mathrm{~m} \mathrm{~s}^{-1}$ on average, whereas the mean wind speed in summer is approximately $5 \mathrm{~m} \mathrm{~s}^{-1}$. The flat temperature maximum leads to a nearly constant outgoing longwave radiation in summer. In summer, variations in the reflected shortwave radiation dominate the interannual variability of the net radiation. The interannual variability in reflected shortwave radiation during the summer is $10 \%$. The absolute interannual variability in incoming and reflected radiation is 14 and $16 \mathrm{~W} \mathrm{~m}^{-2}$ respectively, both far higher than the absolute interannual variability in the longwave components which is 3 and $1 \mathrm{~W} \mathrm{~m}^{-2}$ for the incoming and outgoing components, respectively. This means that variations in ablation from year to year at $1020 \mathrm{~m}$ a.s.l. are most likely driven primarily by variations in the shortwave balance (see below).

The mean seasonal cycle of the radiative components is shown in Figure 5. This figure shows a large net radiation during the summer months, and a radiative deficit of about

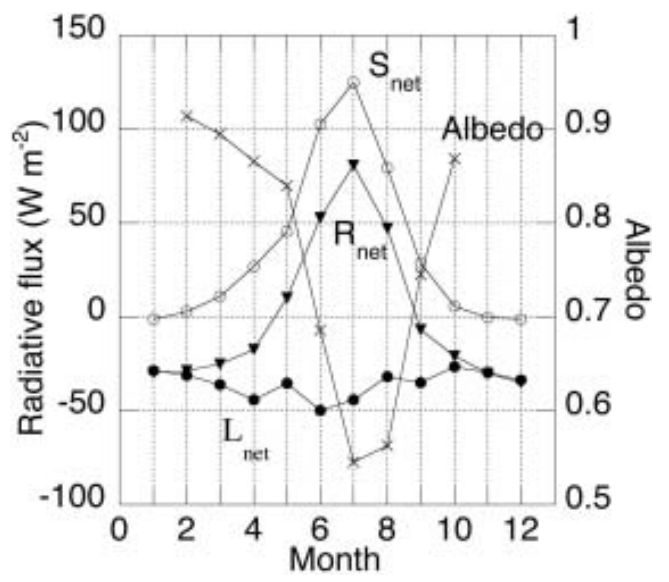

Fig. 5. Average seasonal cycle of the radiation balance (19972002), based on monthly means, of incoming shortwave radiation, reflected shortwave radiation, albedo, incoming longwave radiation and outgoing longwave radiation at site 6 .

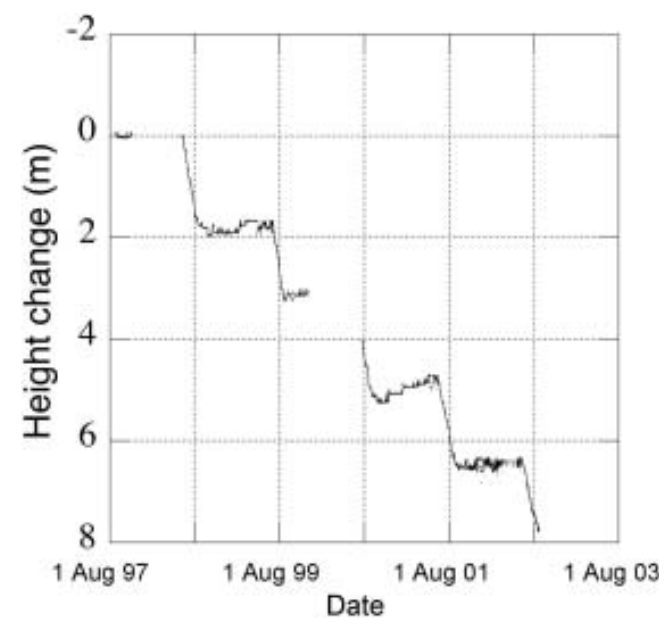

Fig. 6. Cumulative change of elevation as measured with the sonic height ranger at site 6 over 5 years, with 1 August 1997 chosen as reference level. Data gaps are estimated based on stake readings.

$40 \mathrm{~W} \mathrm{~m}^{-2}$ in winter. The albedo pattern is somewhat asymmetric over the summer. In early summer the winter snowpack has to be melted, leading to intermediate albedo values of 0.7. Bare ice is exposed in July and August, leading to albedo values of 0.55 . The first snow arrives in late August, melt ceases and the albedo increases rapidly to values of $>0.8$.

\subsection{Sonic height ranger measurements}

In order to study the ablation process in more detail, we also measured the change of surface height using a sonic ranging device mounted on a tripod. The tripod was drilled into solid ice on a stiff construction to prevent leaning. This implies that we can safely assume that the tripod itself is not sinking relative to the surface, and data need no corrections for leaning. Results of sonic height ranger measurements are presented in Figure 6. Unfortunately there was some data loss over two winter periods because the sensors were too close to the surface. As a result, we do not have a good record of winter accumulation. The three remaining years show winter accumulation, which varies from 20 to $55 \mathrm{~cm}$ snow. Note that we have no density data to convert the wintertime data to mass. For the summer period we can use a density of $900 \mathrm{~kg} \mathrm{~m}^{-3}$, as there is ice exposed at the surface. From the sonic height ranger data it can be concluded that the ablation season starts around 1 July in 1999 and around 10 June in 2001 and 2002. For the two other years no data are available.

\section{ENERGY BALANCE AND MELT}

We can calculate the ablation from the weather station data. However, a full energy-balance calculation over the entire period is not feasible due to the limitations of the dataset. As mentioned, sonic height ranger data are not available for two winter seasons and no density measurements are available. For this reason, we selected the period 22 July20 August of each year to calculate the ablation. This is the longest summer period with continuous meteorological and sonic height data over all 5 years. Over this period when ice is exposed and temperatures are near zero, the energy balance reduces to a summation of net radiation and sensible and latent heat. 
Table 5. The ablation over a summer month as observed with the sonic height ranger, and the ablation derived from stake readings over a full mass-balance year. Data are converted to mw.e. by assuming a density of $900 \mathrm{~kg} \mathrm{~m}^{-3}$ for ice

\begin{tabular}{ccc}
\hline$n$ & $\begin{array}{c}\text { 22 July-20 August } \\
\text { sonic height ranger }\end{array}$ & $\begin{array}{c}\text { Late August (year } n-1) \text {-late } \\
\text { August (year } n \text { ) stake readings }\end{array}$ \\
\hline 1998 & 0.52 & 1.59 \\
1999 & 0.86 & 1.46 \\
2000 & 0.77 & 1.26 \\
2001 & 0.59 & 1.03 \\
2002 & 0.36 & 1.30 \\
\hline
\end{tabular}

Table 5 lists the ablation over this summer period by individual year according to the sonic height ranger data. It should be noted that as we visit the sites only once a year, these data are not confirmed independently by stake observations. From Table 5 it can be concluded that the melt varies substantially $(0.36-0.86 \mathrm{~m}$ w.e.) from year to year during this period. This is mainly due to a shift in the timing of the melt to earlier or later parts of the summer. Variations in the surface mass balance as observed by the stake readings over these 4 years are clearly smaller, as can be observed in Tables 1 and 5, and indicate that the shift in the timing is indeed responsible for the strong variations over the period 22 July-20 August.

Net radiation is measured, but the turbulent flux has to be calculated. From the radiation measurements it can easily be calculated that on average $84 \%$ of the energy needed to explain the observed melt originates from net radiation. For this reason, we used the simplest approach to calculate the turbulent flux. A second justification for the simple approach is the fact that our data are too limited to allow for changing surface roughness conditions and stability corrections. No humidity measurements are available for the first 4 years, so we have to assume a constant relative humidity. This implies that the sum of latent- and sensible-heat flux is approximated by a linear function of the temperature difference between surface and measurement height. Therefore, we simply assumed the turbulent flux to be proportional to the product of the temperature and wind speed. By doing so we can minimize the difference between observed and modelled ablation over the 5 years. Results of the best fit are shown in Figure 7 for the individual years. The mean difference between the model and observations integrated over a month is $9 \mathrm{~cm}$ w.e., or $13 \%$. Somewhat poorer results are obtained if the variability of the wind speed is neglected and hence only temperature variations are taken into account. The mean difference is then $11 \mathrm{~cm}$ w.e., or $15 \%$. Figure 7 shows excellent agreement for the summers of 1997 and 1998, but for parts of the two other summers differences are substantial.

\section{DISCUSSION AND CONCLUSIONS}

We presented a 13 year dataset of surface mass-balance measurements from a transect in West Greenland. Key results are the average annual surface mass-balance gradient of $3.7 \times 10^{-3} \mathrm{~m} \mathrm{~m}^{-1}$, and a mean ELA of $1534 \mathrm{~m}$. There is no trend over the period of observations, but a weak 4 year periodicity is observed.
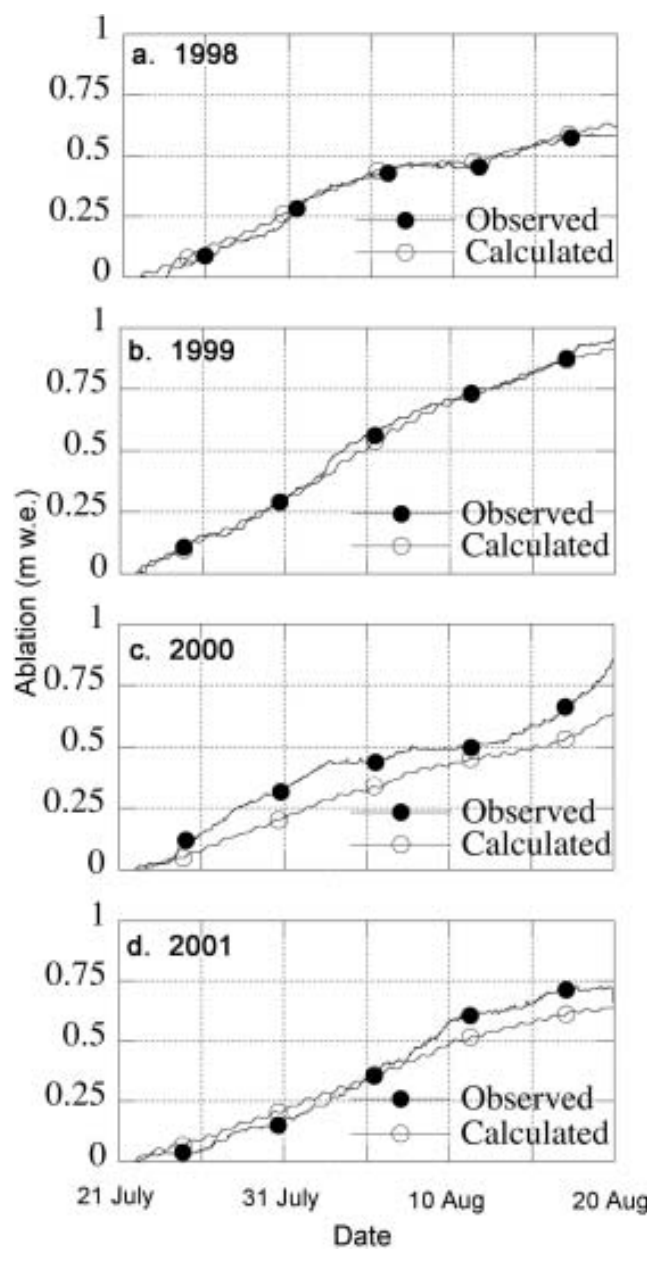

Fig. 7. Modelled and observed ablation over the period 22 July2 August during 4 years of observations: (a) 1998; (b) 1999; (c) 2000; and (d) 2001.

AWS data from a site in the ablation zone show that interannual variability in the energy balance is caused mainly by fluctuations in shortwave radiation. The nearly constant temperatures close to the melting point in summer limit the outgoing longwave radiation and to some extent the net longwave radiation, though variations due to differences in cloudiness are to be expected. By far the largest term in the energy balance is the net radiation component $\left(61 \mathrm{~W} \mathrm{~m}^{-2}\right)$, which accounts for $84 \%$ of the total energy for melting, leading to ablation rates of typically $2 \mathrm{~cm}$ w.e. $\mathrm{d}^{-1}$ in summer at this location.

Ideally one would like to do a full energy-balance calculation over the entire year, which considers a more detailed treatment of the turbulent flux and subsurface processes. For this reason, we installed equipment for yearround turbulence measurements in 2003. These measurements, which are not yet available, will allow us to study in more detail the turbulent fluxes and might help to interpret the differences in Figure $7 c$ and d. At present, we cannot exclude that they are partly explained by errors in the estimated turbulent flux. Another possibility for the observed differences in Figure $7 \mathrm{c}$ and $\mathrm{d}$ might be local ablation variations as suggested by Braithwaite and others (1998). However, this does not exclude the use of the meteorological data of the AWS and the mass-balance observations for validation of atmospheric models aiming to simulate the 
meteorology and ablation of the marginal zone of the ice sheet in West Greenland (e.g. Box and others, 2004).

\section{ACKNOWLEDGEMENTS}

We thank W. Boot, H. Snellen and all the people involved in the data collection. Useful reviews by R. Braithwaite and G. Hamilton helped to improve the clarity of the paper. Additional thanks to the scientific editor T. Murray for her efforts. This project was financed most recently by the Spinoza Program of the Dutch National Research Programme, and a Netherlands Antarctic Program (NAAP) proposal from the Dutch Science Foundation.

\section{REFERENCES}

Box, J.E., D.H. Bromwich and L.-S. Bai. 2004. Greenland ice sheet surface mass balance for 1991-2000: application of Polar MM5 mesoscale model and in-situ data. J. Geophys. Res., 109(D16), D16105. (10.1029/2003JD004451.)

Braithwaite, R.J. and O.B. Olesen. 1989. Detection of climate signal by inter-stake correlations of annual ablation data, Qamanârssûp sermia, West Greenland. J. Glaciol., 35(120), 253-259.

Braithwaite, R.J., T. Konzelmann, C. Marty and O.B. Olesen. 1998. Reconnaissance study of glacier energy balance in North Greenland, 1993-94. J. Glaciol., 44(147), 239-247.
Greuell, W. and W.H. Knap. 2000. Remote sensing of the albedo and detection of the slush line on the Greenland ice sheet. J. Geophys. Res., 105(D12), 15,567-15,576.

Greuell, W., B. Denby, R.S.W. van de Wal and J. Oerlemans. 2001. Correspondence. 10 years of mass-balance measurements along a transect near Kangerlussuaq, central West Greenland. J. Glaciol., 47(156), 157-158.

Reeh, N. 1991. Parameterization of melt rate and surface temperature on the Greenland ice sheet. Polarforschung, 59(3), $113-128$

Six, D., A. Letréguilly and L. Reynaud. 2001. Greenland ice-sheet mass-balance distribution: a variance analysis of existing field data. J. Glaciol., 47(158), 441-451.

Thomas, R.H. 2004. Greenland: recent mass balance observations. In Bamber, J.L. and A.J. Payne, eds. Mass balance of the cryosphere: observations and modelling of contemporary and future changes. Cambridge, Cambridge University Press.

Thomsen, H.H. 1987. Continued glaciological work north-east of Jakobshavn, West Greenland. Grønl. Geol. Undersøgelse Rapp. 135, 84-87.

Van de Wal, R.S.W. 1996. Mass-balance modelling of the Greenland ice sheet: a comparison of an energy-balance model and a degree-day model. Ann. Glaciol., 23, 36-45.

Van de Wal, R.S.W. 2004. Greenland mass balance modelling. In Bamber, J.L. and A.J. Payne, eds. Mass balance of the cryosphere: observations and modelling of contemporary and future changes. Cambridge, Cambridge University Press.

Van de Wal, R.S.W. and 11 others. 1996. Mass balance measurements in the Søndre Strømfjord area in the period 1990-1994. Z. Gletscherkd. Glazialgeol., 31, 57-63. 